\title{
Serving Teaching and Research in Higher Vocational College English Teaching
}

\author{
Zhen Yang \\ Tianjin Maritime College 300350
}

\begin{abstract}
Key words: Higher vocational college English teaching; Service oriented teaching; Teachers; Students

Abstract: The construction of service oriented teaching system in higher vocational college English teaching, help to strengthen students' practical English application abilities and translation skills, promote the balanced development of English listening, speaking, reading and writing teaching. This article will, for example, discussion service system of teaching in English teaching in higher vocational colleges, and puts forward personal advice, hope to provide reference for higher vocational college English teaching.
\end{abstract}

\section{Introduction}

Service oriented teaching is a kind of new teaching idea, belongs to the teaching system of comprehensive services, and can meet the social demand for English translation talents, improve the students' English skills, to cultivate students quick response ability of English. This article will introduce the definition of service oriented teaching, this paper discusses the current English teaching problem in higher vocational colleges, and from the use of integrated service teaching system, do a good job in English translation teaching, cultivate students' English awareness and enhance the vitality of the culture of English teaching are discussed in four aspects for example in serving the teaching plan of the higher vocational college English teaching.

\section{The definition of service oriented teaching}

Two basic functions of service-oriented teaching is "education" and "service", its guiding philosophy is "people-oriented", advocating the students learning knowledge in the relaxed and happy environment and guides the student to transform knowledge into practical application ability, then professional foundation for future employment.

\section{The current English teaching in higher vocational colleges}

3.1Classroom teaching method is relatively single. Analysis according to the ministry of education, the current college English classroom teaching method is relatively single, teachers in the use of some teaching mode in English teaching activities are basically no longer fusion other teaching methods, such as the use of situational teaching method for English education is not combined with interactive teaching method, task-based teaching method and other teaching methods. Single teaching method is not conducive to arouse students' interest in listening to lectures, it is difficult to effectively improve the students' ability of English translation.

3.2English teaching can not meet the needs of the social market of professional talents. At present, most of the higher vocational college English teaching and English posts a serious disconnect between the concrete work, teaching content can not meet the market demand for professional talents of society. Most of the teachers in teaching English, too much emphasis on grammar and discourse teaching, there is no comprehensive guide students to understand the specific professional knowledge of English. For example, business English, tourism English, hotel English and cruise service professional English knowledge of English, the students' English translation based on relatively weak, practical working skills is low. 


\section{In serving teaching plan of the higher vocational college English teaching}

4.1Using the integrated service teaching system. Serving teaching belongs to the comprehensive service system, first in English teaching, the teacher should use this comprehensive service teaching system science, collection of task-based teaching, scene teaching, interactive teaching, small class teaching and teaching the advantages of various teaching methods such as cooperation, build vibrant English classroom, with the tools of modern teaching technology, in the professional knowledge in English words, grammar, listening, reading, writing and so on various aspects of knowledge and micro video class, assigns appropriate learning tasks for the students, strengthen the classroom interaction, and for the students to establish a study group, offer the platform of the cooperation study, help students solve various difficulties in English learning. In addition, the teacher should also use network technology to form a campus network English. Do a good job after class English teaching to strengthen the communication with students and regularly updated English network system of knowledge to cultivate the students' English thinking. Currently there are a lot of college students is easy to put the definite article and the indefinite article a mix-up, teachers can be fine in the campus network in teaching English speak both the using method of the article, cited a typical example to assist students to grasp the usage of these two articles, such as:

a) I had a bath before dinner.

b) Have a biscuit.

c) I had a letter from him yesterday.

d) She always buys flour, sugar and tea at the grocer's.

4.2Do a good job in English translation teaching. English translation teaching is the key of the higher vocational college English teaching, teachers should guide students to be familiar with business English, tourism English, hotel services and cruise service English commonly used in English, such as training high quality English translation talents for the society. When parsing the business English, teachers can be divided into four parts, namely, "said can accept the task", "report work progress", "said have difficulty", "language commonly used in the company called", and then combined with the four headings, with clear courseware for students to list the english-chinese translation phrase. As "said can accept the task" spoken English translation mainly includes:Yes, I see, I will try my best, I don 't think there' re any problems, I will try to work it out, I will report to you as soon as I finish it. In terms of interpretation of the guide, the teacher can let students practice guides, remind pay attention to safety, about shopping, explanation phrase or replacement schedule and related matters in English translation. Service at the hotel English teaching, teachers should inform students of hotel management commonly used English mainly divided into the service industry, hotel English is commonly used phrase and restaurants. In cruise service in English teaching, teachers should according to different cruise service jobs for oral practice.

4.3Cultivate the students' English awareness. English teachers should make full use of consecutive interpretation teaching to strengthen students' English listening and improve the students' simultaneous translation skills. In English teaching of consecutive interpretation activities, students will often hear the words to the similar or the same pronunciation (such as beast and feast), also will have more than a word meaning phenomenon (such as gift can represent nouns gifts, gifts, award, talent, very cheap things, it is easy to do, can also be said transitive verb gives..., giving), it brought certain difficulty to the translation work. For this problem, the teacher should pay attention to training students perception ability. First, with the aid of multimedia tools for students to play video English listening without subtitles, lets the student speculated that the meaning of the words from the visual sense, quickly record by what they hear. Second, teachers should guide students shorthand contains more than one meaning of the word, enlarge students' vocabulary and English reading, guide students to practice listening. To consolidate the foundation of the students in vocabulary, listening comprehension, grammar, English pronunciation and native language foundation of basic skills, etc, gradually improve students' ability in memory and listening comprehension level. For example, in to let the students listen to the passage of A noble gift before, for students to list the key words and phrases: noble, copper, monument, support, statute, framework, liberty, transport, present, site, sculptor, pedestal and actual. Then, let the students 
memorize these key words quickly. Next, the teacher can play listening, let the students listen to while listening to the content. After hearing was over, allow students to translate the Chinese meaning of this passage to retell the content what you hear in English. The last, the teacher can show students English original text and the key sentence patterns. On the other hand, teachers can put the short-term memory training and memory training over a long period of time, the combination of guiding students flexible use of grammar rules and different meaning. This not only helps to train students of memory, but also can cultivate students' ability of agile response and good language sense, strengthening the students' English translation skills.

4.4Enhance the vitality of the culture of English teaching. Teachers should together constantly enhance the vitality of the culture of English teaching in higher vocational colleges, hold all kinds of English cultural activities for the students on a regular basis, such as "interpreting competition", "English speech competition", "English concert", "the English tongue twister contest", "English drama performance", "beautiful English" and "listening", such as rich and colorful activities. Let the students in the process of English cultural activities promote comprehensive ability and strengthen the English translation skills.

\section{Conclusion:}

To sum up, the teacher in the English teaching in higher vocational schools should be science teaching in comprehensive service system, do a good job in professional English teaching, for the country to train high skilled professionals. Using English teaching of consecutive interpretation activities to cultivate the students' English awareness, improve the students' English listening level. By organizing a variety of English cultural activities, strengthen students' ability in English translation, thus improve the students' ability of professional services.

\section{References:}

[1] Liu Hui. The input of culture in higher vocational English teaching and the effective way to analysis [J]. Journal of huazhong agricultural university, 2013 (21)

[2] $\mathrm{Wu}$ Guoquan. The cross-cultural education in higher vocational oral English teaching to carry out the strategy analysis [J]. Journal of education teaching BBS, 2015 (8)

[3] Liu Lin. Based on service oriented teaching mode in college English teaching in the application of feasibility analysis [J]. Foreign language audiovisual education, 2014 (7)

[4] Ma Xiulin, Zhao Guoqing, Wu Tong. Discusses how to optimize higher vocational oral English teaching [J]. China audio-visual education, 2014 (12) 